Article

\title{
Integrating Airborne Laser Scanning and 3D Ground-Penetrating Radar for the Investigation of Protohistoric Structures in Croatian Istria
}

\author{
Federico Bernardini ${ }^{1,2, *}$, Giacomo Vinci ${ }^{2,3, *(D)}$, Emanuele Forte ${ }^{3} \mathbb{D}$, Arianna Mocnik ${ }^{4}$, Josip Višnjić 5 \\ and Michele Pipan ${ }^{3}$ (D)
}

1 Dipartimento di Studi Umanistici, Università Cà Foscari Venezia, Dorsoduro 3484/D, 30123 Venezia, Italy

2 Multidisciplinary Laboratory, The Abdus Salam International Centre for Theoretical Physics, Strada Costiera 11, 34151 Trieste, Italy

3 Dipartimento di Matematica e Geoscienze, Università di Trieste, Via Weiss 2, 34128 Trieste, Italy; eforte@units.it (E.F.); pipan@units.it (M.P.)

4 Esplora srl, Spin-Off Accademico dell'Università Degli Studi di Trieste, Via Giglio Padovan 10, 34138 Trieste, Italy; arianna@esplorasrl.it

5 Odjel za Kopnenu Arheologiju, Hrvatski Restauratorski Zavod, Juršići 7, 52342 Svetvinčenat, Croatia; jvisnjic@hrz.hr

* Correspondence: federico.bernardini@unive.it (F.B.); giacomo8vinci@gmail.com (G.V.)

check for updates

Citation: Bernardini, F.; Vinci, G.; Forte, E.; Mocnik, A.; Višnjić, J.; Pipan, M. Integrating Airborne Laser Scanning and 3D Ground-Penetrating Radar for the Investigation of Protohistoric Structures in Croatian Istria. Appl. Sci. 2021, 11, 8166. https://doi.org/10.3390/ app11178166

Academic Editor: Filippos Vallianatos

Received: 5 August 2021

Accepted: 29 August 2021

Published: 3 September 2021

Publisher's Note: MDPI stays neutral with regard to jurisdictional claims in published maps and institutional affiliations.

Copyright: (c) 2021 by the authors. Licensee MDPI, Basel, Switzerland. This article is an open access article distributed under the terms and conditions of the Creative Commons Attribution (CC BY) license (https:/ / creativecommons.org/licenses/by/ $4.0 /)$.
Abstract: We present the investigation of two rather ephemeral archaeological sites located in the municipality of Oprtalj/Portole (Croatian Istria) by means of integrated archaeological, geophysical and remote sensing techniques. The results obtained confirm the first interpretation of these contexts; a protohistoric burial mound and a small hillfort, respectively. We further obtained detailed information about both deposits through 2D and 3D remote sensing and geophysical studies that produced maps, volumes, profiles and cross-sections. At the first site, the volume reconstruction of both the inner stone core and the superimposed earth of the putative stone mound also allowed us to estimate the labour necessary to erect the structure. In conclusion, our study demonstrates that the integrated approach can be valuable not only to acquire novel data about the archaeological deposits but also to calibrate future investigations and to plan effective measures for heritage management, monitoring and valorization.

Keywords: Airborne Laser Scanner; Ground-Penetrating Radar; 3D virtual models; digital archaeology; protohistory; Croatian Istria

\section{Introduction}

Since archaeological excavations are costly and time-consuming, the combined analysis of high-resolution Airborne Laser Scanning (ALS) and Ground-Penetrating Radar (GPR) data is dramatically changing the investigation and documentation of archaeological features. The integration of cutting-edge, non-destructive photogrammetric and remote sensing techniques is providing crucial information about their geometry, topography and spatial relationship with other natural or anthropogenic features [1-6].

In the last decade, a key contribution to this achievement has been imaging technologies such as Airborne Laser Scanning (hereafter ALS) and Ground-Penetrating Radar (hereafter GPR), which enable the production of detailed 2D and 3D maps of the archaeological evidence and the surrounding topography of the landscape at centimetre resolution, and which are now fairly comparable with other destructive techniques such as excavations [7-14]. This information is of paramount importance for different objectives, such as identifying possible anthropogenic features, assessing the thickness of anthropogenic deposits and best calibrating future investigations (e.g., indicating the most promising location for excavations), allowing us to plan effective measures for heritage management, monitoring and valorization [15-18]. 
Despite its great potential for archaeology, the integration of these two techniques is still rather uncommon and applications have mostly addressed historical contexts with regular and easily detectable structures (see, e.g., [19-22]).

This paper presents the combined analysis of high-resolution ALS and 3D GPR data for the investigation of two small archaeological sites located in the municipality of Oprtalj/Portole (Croatian Istria; Figure 1), which have been attributed to the protohistoric period (namely Bronze and Iron Ages, ca. 2200-150 BC).

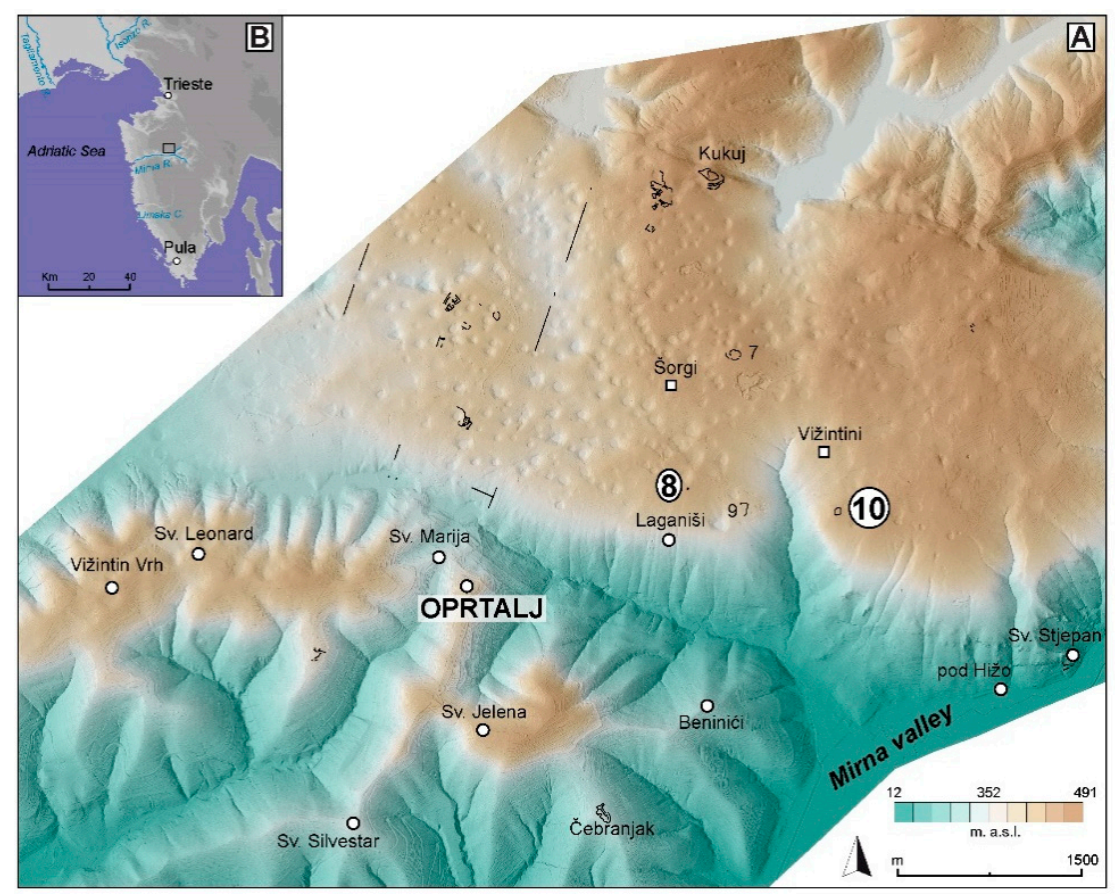

Figure 1. (A) Position of the investigated sites 8 and 10, main archaeological sites (white dots and black lines; see Bernardini and Vinci [23]) and modern localities mentioned in the text (white rectangles). (B) Position of the area in the Istrian peninsula.

Previous research in the area was conducted with the aim of understanding the diachronic development of the archaeological landscape of a largely unexplored sector of the Istrian peninsula. This included the acquisition, processing and analysis of highdefinition ALS data combined with the examination of aerial photographs, historical cadastral maps and repeated fieldwork surface surveys. The investigations, carried out over about 30 square $\mathrm{km}$, allowed us to identify and describe several unreported prehistoric, protohistoric and Roman sites and to obtain detailed topographic information about the already known ones [23].

The selection of a probable burial mound (Figures 1 and 2, feature 8) and a small hillfort (Figures 1 and 2, feature 10), both likely erected in pre-Roman times, for further non-invasive investigations was motivated by several reasons, including the richness in archaeological finds at the surface, the limited size of detected structures, the absence of dense vegetation, some logistical evaluations, the suitability of these features for future excavations and ultimately the consistent evidence, in the Vižintini village surroundings, of a well-preserved landscape dated back to the protohistoric period (namely Bronze and Iron Ages, ca. 2200-150 BC; Figure 1).

The analysis of GPR data collected at both sites and integrated with ALS allows us to describe in detail the morphology of the structures and associated earth deposits and provide additional information for the interpretation of both complexes and the assessment of further investigations. 


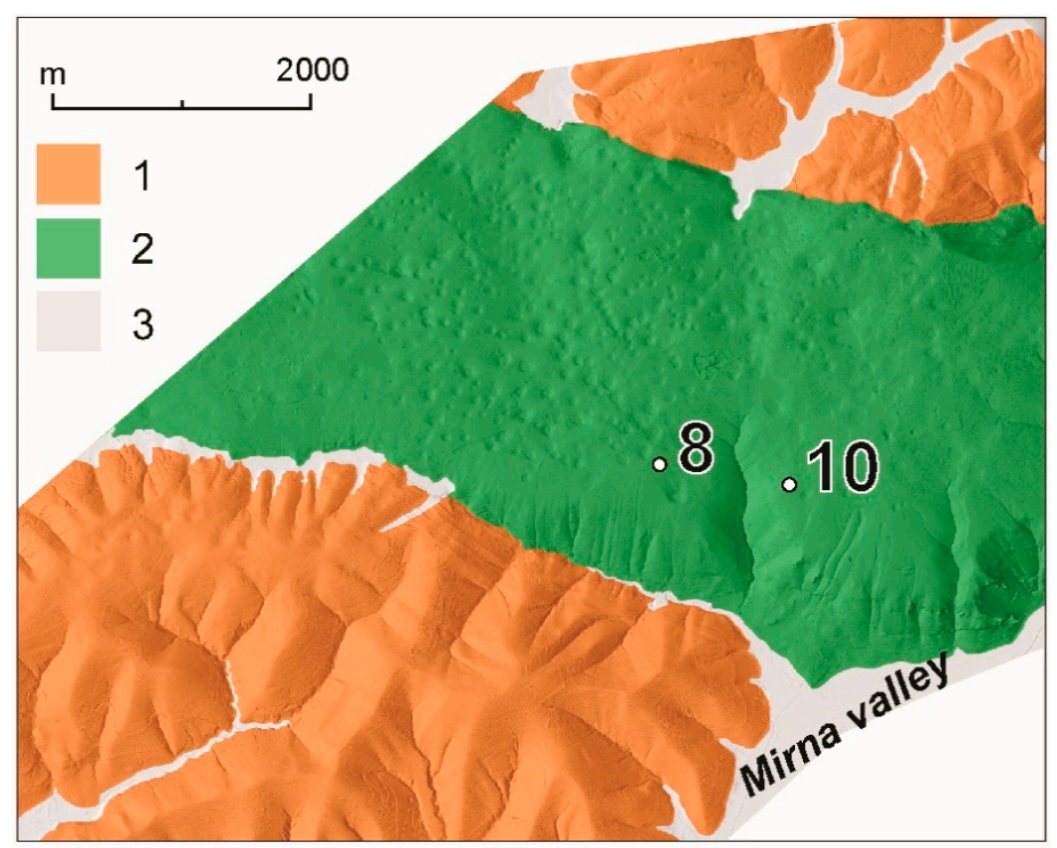

Figure 2. Position of features 8 and 10 and geological map of the investigated area. 1: Flysch deposits (Eocene); 2: Rudist limestone, dolomite and breccia (Cretaceous); 3: Quaternary deposits (mainly Holocene). Modified after Felja et al. [24].

\section{Geographic, Geological and Archaeological Background}

Features 8 and 10 (Figures 1 and 2) are located at the southern edge of the relatively flat karst plateau close to Oprtalj/Portole, at an average height of about $400 \mathrm{~m}$ a.s.l. (Figure 1, nn. 8 and 10). They are divided by a deep narrow valley of an ephemeral watercourse which drains into the Mirna/Quieto river. This latter perennial river and its wide valley flanks the southern side of the investigated area and represents an important waterway which has connected coastal Istria with the inlands since prehistoric times [25].

The plateau is made of Cretaceous limestone, dolomite and breccia and overlooks southward a hilly sector made of marls and sandstones (Eocene Flysch deposits; [24,26,27]) divided by the Mirna valley (Figure 2).

The overall area is rich in archaeological features consisting of prehistoric, protohistoric and Roman sites ([23] and references therein). Close to the two investigated structures, the main evidence in the area is represented by the Laganiši cave, occupied for a long period spanning from Neolithic to the Roman times (around 5000 BC-4th century AD), which was investigated in recent years ([28]; Figure 1, Laganiši).

On the contrary, the two features here analysed were unknown before the recent publication of the results of the ALS survey [23], as well as two other protohistoric fortified structures located in their surroundings. Feature 9 is an irregular fortification (about $130 \times 60 \mathrm{~m}$ in size) located immediately west of site 10 and at the edge of the scarp of a deep narrow valley placed between them (Figure 1, feature 9). Feature 7 is an elliptical structure, about $80 \mathrm{~m}$ large and showing an additional south-western wall, located north of a limestone quarry between Vižintini and Šorgi villages (Figure 1, feature 7).

Hundreds of similar fortified settlements, located on hilltops and protected by imposing dry-stone ramparts, mark the landscape of the north-eastern Adriatic region between the Trieste Karst plateau, the Istria peninsula and the Dalmatian islands. These villages were settled for many centuries, in some cases up to the arrival of the Romans in the area in the early 2nd century BC, and shared homogenous traits in pottery assemblages and funerary practices [29]. Among these are burial mounds widely documented in the whole region with negligible differences and generally attributed to Early and Middle Bronze Age (ca. 2200-1350 BC). Other, larger protohistoric hillforts known in the area by previous research carried out in the late nineteenth and early twentieth century are located close to 
the investigated sites, at Kukuj, Oprtalj, Sv. Jelena, Čebranjak, Beninići, Sv. Stjepan and perhaps Gradinje and Vižintin ([30]; Figure 1).

\section{Materials and Methods}

\subsection{Airborne Laser Scanning}

High-resolution ALS data, featuring at least 20 points per square meter, were acquired by Vectra company in winter 2018 using a Eurocopter EC 120B, flying at a mean altitude of $500 \mathrm{~m}$ with a speed of $55 \mathrm{kts}$ and equipped with a GPS receiver Novatel OEV/OEM4, a LiDAR instrument Riegl LMS-Q780 (pulse repetition rate of $400 \mathrm{kHz}$ ) and a photo camera Hasselblad. Processing and analyses of collected data were carried out by the team of the Multidisciplinary Laboratory of the "Abdus Salam" International Centre for Theoretical Physics (ICTP, UNESCO) using the free open-source software SAGA GIS, QGIS and Relief Visualization Toolbox to produce Digital Terrain Models (DTMs) and different visualizations. Among these are the Slope and the Simple Local Relief Model that are presented in this contribution (see also [23] for details about the processing of data).

\subsection{D Ground Penetrating Radar}

The implementation of efficient and portable multi-antenna (or multi-array) GPR instruments, accurate synchronized positioning systems (RTK GPS and topographic total stations) and the demand for 3D subsurface imaging are pushing towards a rapidly growing application of 3D GPR to near-surface studies (see e.g., [31-34]).

The 3D GPR dataset were acquired on feature 8 and feature 10 using the MiniMIRA array GPR (Malå Geoscience, Sweden) equipped with 5 transmitting and 4 receiving $400 \mathrm{MHz}$ shielded antennas, allowing the collection of 8 parallel profiles with a constant distance equal to $8 \mathrm{~cm}$, thus forming a swath of $56 \mathrm{~cm}$ wide. To optimize the spatial resolution, we set a trace spacing also equal to $8 \mathrm{~cm}$, obtaining a constant in-line and cross-line coverage.

The system was connected with an electromechanical odometer for triggering and with RTK GPS for absolute positioning with centimetric accuracy. This allowed us to perform the topographic correction to the GPR volumes, and properly reconstruct the real geometry, depth and slope of the buried surface, in particular in the case of feature 8 , which exhibited a more complex topography.

We applied a standard processing sequence (zero drift removal, background removal, bandpass filtering, amplitude recovery function encompassing spherical divergence and other attenuation effects) on each swath, to enhance the Signal to Noise Ratio. GPR datasets were processed using rSlicers software (DECO Geophysical, Moscow, Russia) as well as an in-house module implemented in Matlab. Swaths were then interpolated within rectangular grids which were hand selected by the operator. This process allowed us to apply FK time migration of the dataset by means of the Stolt algorithm [35] after velocity estimation through hyperbola matching.

Comparison of standard 2D data with the results obtained with this system at controlled test sites showed that complex near-surface conditions can be hardly, if at all, imaged by the $2 \mathrm{D}$ techniques due to the large amount of cross-line information (i.e., out-of-plane reflections and diffractions) recorded into the 2D profile, and are impossible to be resolved by the imaging process if only in-line information is available. This was the case of the study areas, which are characterized by shallow chaotic conditions and geometrically irregular 3D targets.

\subsection{ALS-GPR Integration}

The combined analysis of ALS and GPR data was first carried out through the visual inspection of profiles derived from digital elevation surfaces through the module profile tool available in QGIS 3.

As regards feature $8,3 \mathrm{D}$ points of the stone core surface of the putative burial were extracted from GPR slices and interpolated through the module r.surf.rast available in 
Grass 7 in order to produce a digital surface at $20 \mathrm{~cm}$ resolution (DTM). This allowed the combined 3D visualization of both the topographic and the buried surfaces of the stone cap (feature 8 ) by importing the produced DTMs into CloudCompare.

Afterwards, the area (in square meters) and the volume (in cubic meters) of both the stone structures and the above earthen deposits were calculated through the module Raster Surface Volume available in SAGA GIS.

\section{Results}

\subsection{Feature 8}

According to the ASL-derived data, feature 8 is a circular ridge of $60-70 \mathrm{~cm}$ in height and about $12 \mathrm{~m}$ in diameter, located north-east of Laganiši village and some hundred meters from the above-cited cave with the same name (Figure 1, feature 8). The circular structure is almost outcropping, covered by thin soil and some vegetation and by a modern field division dry wall which crosses the structure along the N-W S-E direction. It testifies for the ancient origin of its construction (Figure 3A,B). As is clearly visible in the ALSderived images and profiles, the eastern margin of the mound is sharp while the western side decreases gradually, with a maximum elevation of about $50 \mathrm{~cm}$ above the ground level. A circular hole is visible on the western side of the modern wall (Figure 4).

Due to the presence of the modern wall in the middle, GPR investigations were carried out over two separated sectors, located, respectively, on the western and on the eastern sides of the modern structure.

On the southern sector of the mound, two anomalies of irregular shape separated by the modern wall, are visible from about $20-30 \mathrm{~cm}$ to about $110-120 \mathrm{~cm}$ from the ground level. The intensity of reflected signals is compatible with a stone core of about $9 \mathrm{~m}$ in diameter with an embossed top (Figure 5, anomalies 1-2; Figure 6A,B).
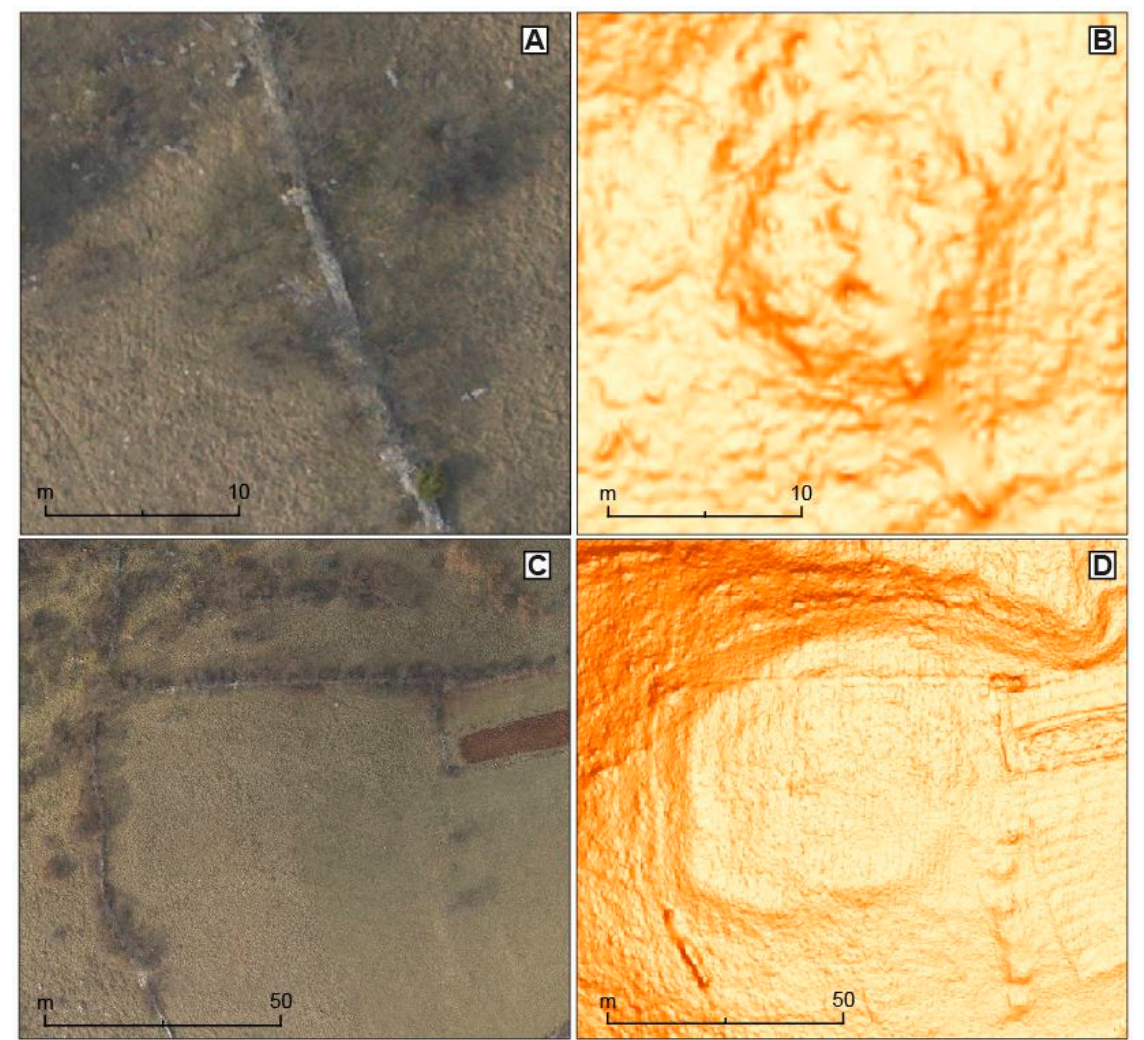

Figure 3. Ortophoto (A) and slope visualization (B) of feature 8; Ortophoto (C) and slope visualization (D) of feature 10. 

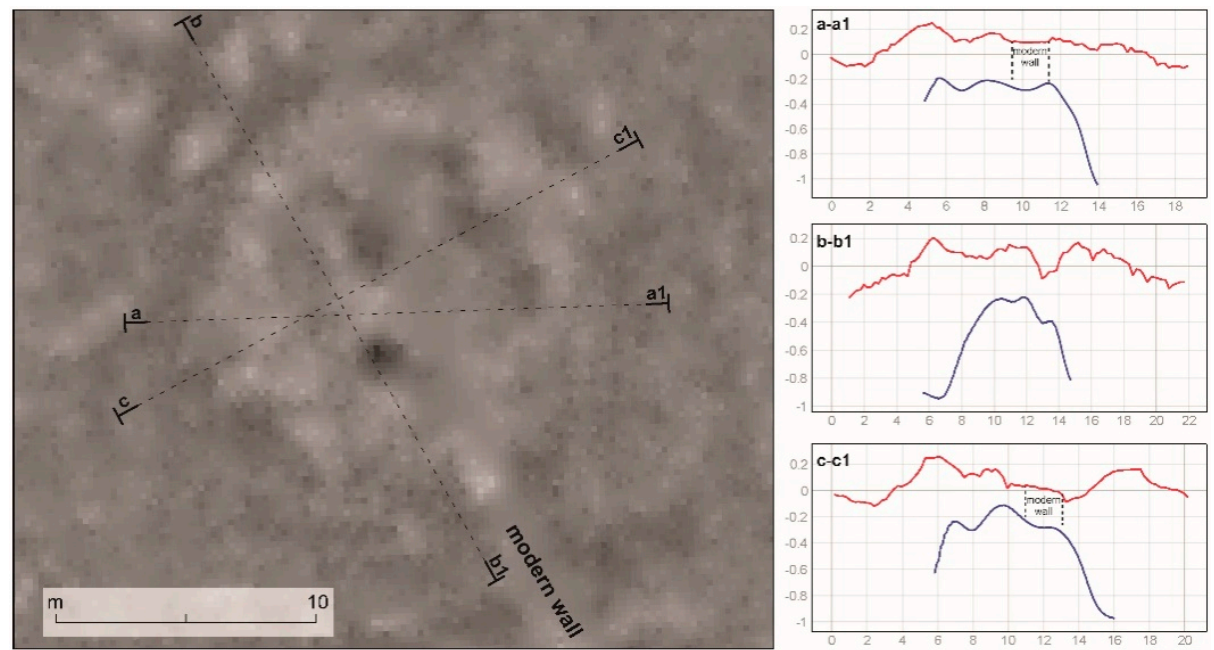

Figure 4. Simple Local Relief Model visualization of feature 8 (left) and interpreted profiles (right) (radius $=20 \mathrm{px}$ ). Dotted lines and associated letters $\mathrm{a}-\mathrm{a} 1, \mathrm{~b}-\mathrm{b} 1$ and $\mathrm{c}-\mathrm{c} 1$ indicate the position of the profiles. The topographic surface profiles from ALS data are in red while the profiles of the underlying stone cap from GPR data are in blue.
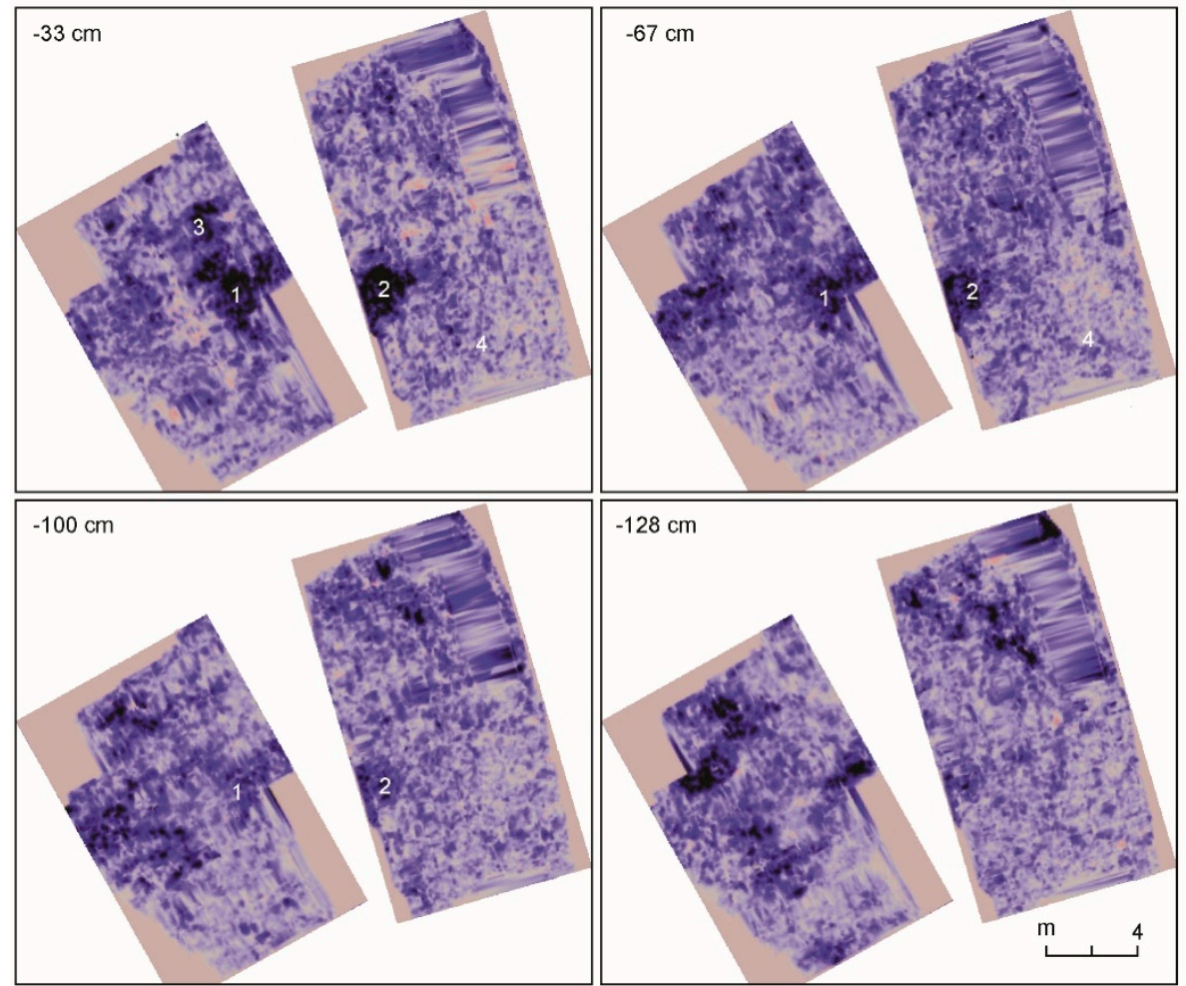

Figure 5. GPR slices of feature 8 at different depth from the ground level. 

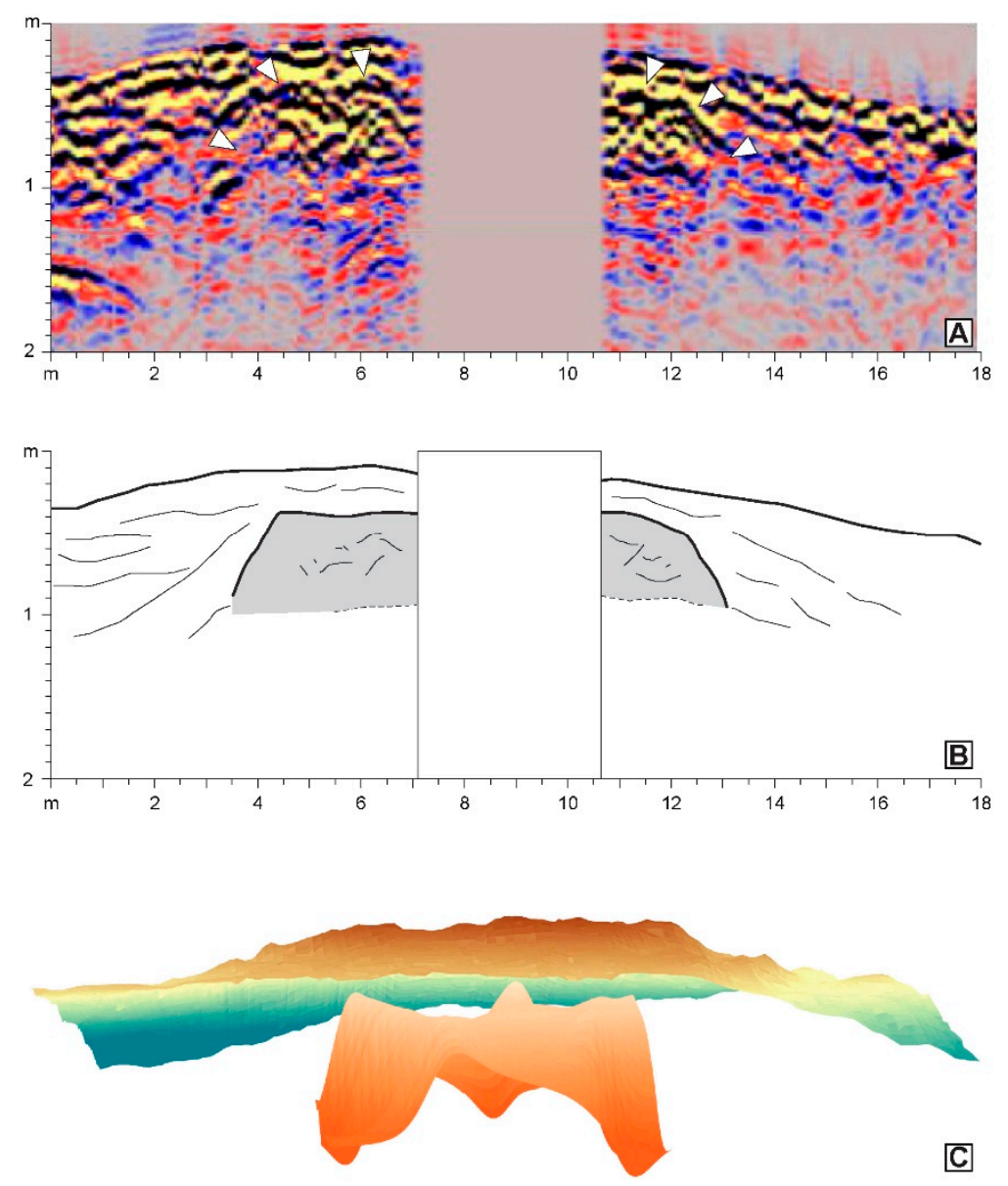

Figure 6. GPR section with the top of the stone core indicated by white triangles (A); GPR interpretation (B); 3D visualization of the topographic surface and the stone core $(3 \times$ magnification) (C). For the location of the GPR section see Figure 4, profile a-a1.

A third circular anomaly is visible on the western sector of the mound from about $30-50 \mathrm{~cm}$ from the ground level (Figure 5, anomaly 3). The circular margin of the structure is not well visible and can be recognized only on the south-eastern sector of the mound between $25-40 \mathrm{~cm}$ from the ground level (Figure 5, anomaly 4), where it appears to be marked by stones and boulders possibly arranged in a row.

DTMs of both the topographic surface (from ALS data) and of the stone cap (from GPR scans) allowed us to produce a 3D visualization of both surfaces (Figure 6C). From those we calculated the overall volume of the mound and the volume of the capstone where the tomb was presumably inserted. The estimated volume of the stone cap corresponds to about $39 \mathrm{~m}^{3}$, while the overall mound volume is roughly $56 \mathrm{~m}^{3}$. This means that the volume of the earth deposits covering the stone cap accounts for approximately $17 \mathrm{~m}^{3}$.

\subsection{Feature 10}

Feature 10 presents an irregular rhombic shape, about $50 \times 50 \mathrm{~m}$ large, which encloses an area of less than 2000 square meters (Figure 3C,D). Small fragments of protohistoric pottery are quite abundant within the fortified area and point to a chronology between Middle and Late Bronze Age [23].

The main structures are easily detectable through the analysis of ALS data. A winding entrance is present at its southern side while the northern part of the fortification is covered by an east-west-oriented modern wall (Figures 3D and 7). Other features visible in the Simple Local Relief Model visualization consist of a linear structure aligned on a north-south direction located south-east of the fortification (Figure 7, n. 5) and some linear features aligned on the east-west direction, which are related to sub-outcropping 
limestone, as confirmed by the analysis of GPR data (Figure 7, OC; see infra). ALS-derived profiles through the structures indicate the perimeter wall rubbles measure around 3-6 m in thickness (Figure 7, nn. 1-4).
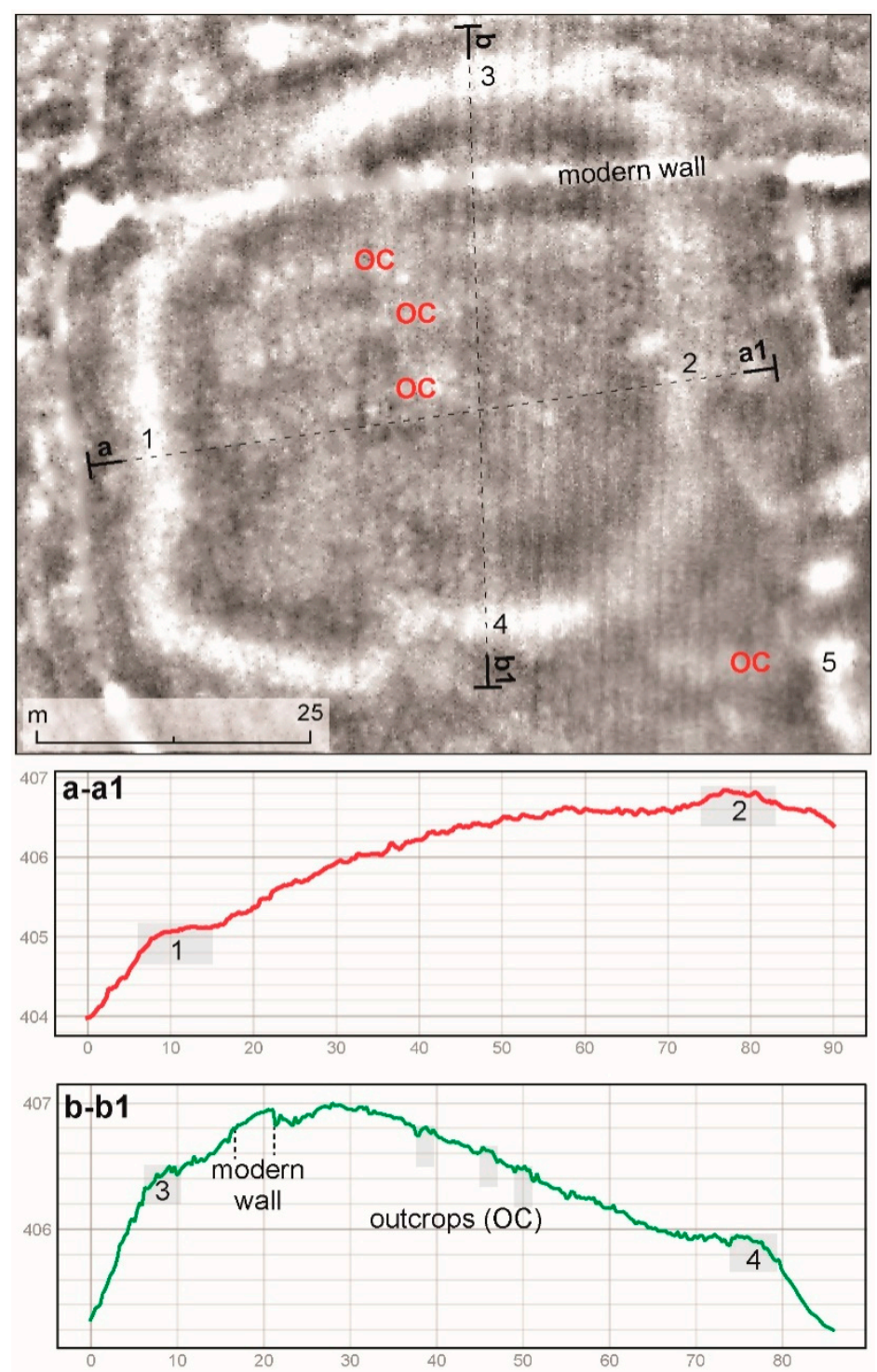

Figure 7. Simple Local Relief Model visualization of feature 10 (top) and interpreted profiles (below) (radius $=20 \mathrm{px}$ ). The dotted lines and associated letters a-a1 and b-b1 indicate the position of the interpreted topographic surface profiles from ALS data.

The results obtained from the GPR survey on feature 10 allow us to better define the perimeter of the enclosure and to identify several additional structures. The perimeter wall structure is clearly visible from about 20 to about $50 \mathrm{~cm}$, progressively disappearing up to about $70 \mathrm{~cm}$ from the ground level (Figure 8, anomaly F). The gateway located on the southern side of the rampart is easily visible at about $30 \mathrm{~cm}$ depth (Figure 8 , anomaly 1 ).

Possible additional circular structures, compatible with the presence of small towers or lookouts and possibly associated with other gaps in the fortification wall, are visible on both the western and eastern sides (Figure 8, anomalies 2-3). The north-south-oriented linear wall structure can be recognized from about 30 to $70 \mathrm{~cm}$ from the ground level (Figure 8, anomaly 4) while several limestone layers, mostly east-west oriented, are found both inside and outside the perimeter of the hillfort (Figure 8, anomaly OC) from around 30 to $100 \mathrm{~cm}$ depth, demonstrating that the structure was built over sub-outcropping limestone and that the landscape remains almost identical from that time. 

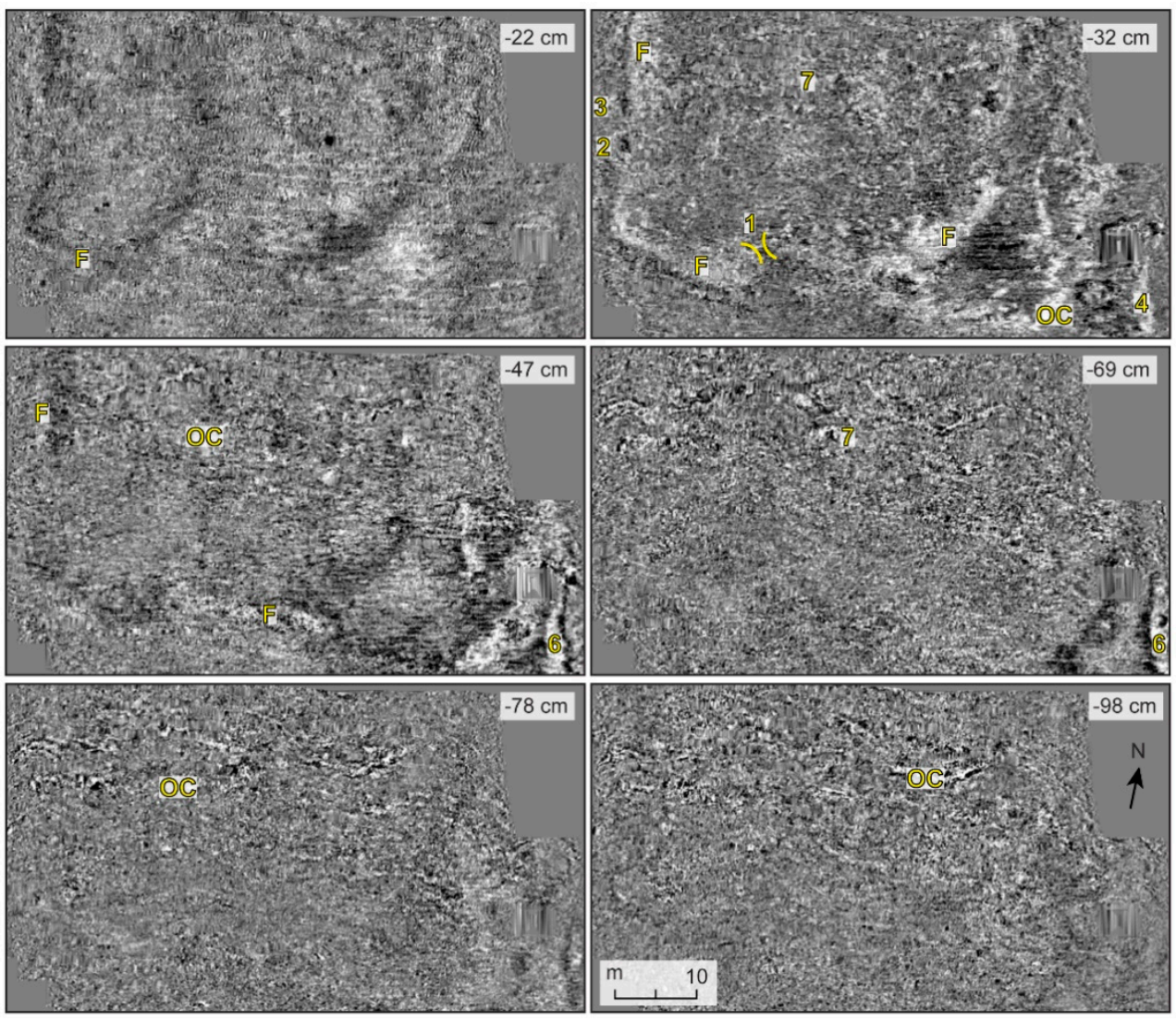

Figure 8. GPR slices of feature 10 at different depths from the ground level $(22$ to $98 \mathrm{~cm}$ depth range): fortification wall (F); limestone layering (OC); the two yellow brackets indicate the area of the southern gateway. See text for the meaning of numbers 1 to 7.

\section{Discussion and Conclusions}

Our study has revealed the potential of coupling high-resolution ALS and GPR data for the identification and description of rather ephemeral archaeological structures (namely feature 8 and 10) with unprecedented accuracy.

The results obtained confirm the first attribution given to these contexts; to a protohistoric burial mound and a small fortified settlement, respectively [23]. The building technique used by the community who settled in the area back in the Bronze Age probably involved mixing together dry-stone walls made of limestone extracted from the substratum and earth deposits. Feature 8 consists of an inner stone cap covered by earthen deposits which originate with a circular bump of about $12 \mathrm{~m}$ in diameter and $80-90 \mathrm{~cm}$ in height. Shape and dimension are comparable with similar tumuli-like protohistoric structures, generally dated to the Early Bronze Age, which have been found elsewhere in the northeastern Adriatic region, particularly in Istria and Friuli [36]. To our knowledge, the best comparisons for building technique and size come from the tumulus n. 6 of Mušego and the burial mound of Barbariga [37,38]. Both structures, of about 11 and $15 \mathrm{~m}$ in diameter, respectively, and less than $1 \mathrm{~m}$ in height, present a stone core in which the rectangular stone slab tomb is inserted, surmounted by an earthen and stone mound. As suggested for feature 8 , the perimeter of the stone cairn is marked by a single row dry-stone line.

Feature 10 is a small hillfort with a roughly rhomboid shape whose ramparts are embedded into a thin soil layer. The overall depth of the archaeological stratigraphy consisting of buried structures and associated earth deposits is about $50 \mathrm{~cm}$. On the southern side, the fortification presents an entrance featured by a narrow and winding passage easily visible on GPR data. Another possible gateway, sided by two associated structures (e.g., towers or lookouts), has been detected on the western side. 
It is not possible to determine whether these structures were built at the beginning of occupation of the area or resulted from the later restorations of the fortification wall. However, this evidence recalls the complex entrance system documented at other larger protohistoric hillforts of the Istrian peninsula, such as Monkodonja [39,40], Určin ([41] with refs.) and Brjuni [42,43]. This type of entrance might have been replicated on a smaller scale by the community which erected the Vižintini hillfort, probably with similar defensive purposes.

Considering their limited size and the strategic position on a slope overlooking the narrow valley, it is likely that both features 9 and 10, as well as site 7 (Figure 1, n. 8-9), functioned as small villages and outposts under the control of a major long-lasting fortified settlement hillfort, e.g., Kukuj, located northward.

As regards feature 8 , the volumes of both the stone core and the whole mound give us a rough idea of the labour involved in the erection of the burial mound. Several ethnological and archaeological studies have proposed different working day coefficients for the construction of dry-stone walls and ditches. In our attempt, we used the working day coefficients proposed by Recchia and Cazzella [44] for the erection of the dry-stone fortification of the protohistoric hillfort of Coppa Nevigata (Apulia) and that proposed by Brown [45] for the excavation of ditches in the Tavoliere Neolithic villages. According to these studies and depending on the raw material used, a single man was capable of transporting and putting in place 1 to 1.25 cubic meters of earth and stone per day. In our case, due to little information about these protohistoric communities, no assumption can be made on the total number of people involved in the work. By using both coefficients ( 1 and 1.25) and establishing the labour of a group of people ranging from 4 to 20 , it follows that the mound might have been erected in a relatively short span of time between a few days and around 1 week (Table 1). Without any alleged intention of historical reconstruction, this result can be of some interest to quantify the labour necessary to erect the burial mound while, on the other hand, to roughly estimate the time needed for the excavation of the whole archaeological deposit.

Table 1. Estimation of the amount of labour involved in building the burial mound feature 8 according to 1 and $1.25 \mathrm{~m}^{3}$ working day coefficients and to different possible groups of people involved.

\begin{tabular}{ccccc}
\hline Total $\mathbf{~ m}^{\mathbf{3}}$ & $\mathbf{m}^{\mathbf{3}}$ Coefficient & Work-Day & People Involved & Days \\
\hline 56 & 1 & 56 & 4 & 14 \\
56 & 1 & 56 & 8 & 7 \\
56 & 1 & 56 & 16 & 3.5 \\
56 & 1 & 56 & 32 & 1.75 \\
56 & 1.25 & 44.8 & 4 & 11.2 \\
56 & 1.25 & 44.8 & 8 & 5.6 \\
56 & 1.25 & 44.8 & 36 & 2.8 \\
56 & 1.25 & 44.8 & 32 & 1.4 \\
\hline
\end{tabular}

In fact, since archaeological excavations are costly and time consuming, volumetric information regarding archaeological deposits combined with 2D and 3D reconstructions derived from both ALS and GPR slices are also crucial for assessing further investigations. These can be carried out through further non-destructive techniques (e.g., repeated surface surveys) or destructive ones (such as corings, small scale/open area excavations) and the best strategies need to be adjusted according to a careful evaluation of costs/benefits and expected results. This regards not only investigations for purely research purposes but also those involving heritage management, monitoring and valorization in which a number of aspects (not exclusively archaeological) and goals must live together and have to be taken into consideration.

Author Contributions: Conceptualization and research design, F.B.; methodology, F.B., G.V., E.F., A.M., M.P.; investigation, F.B., G.V., E.F., A.M., M.P.; data curation, G.V., E.F., A.M.; writing-original draft preparation, F.B., G.V., E.F., A.M., M.P.; writing—review and editing, F.B., G.V., E.F., A.M., J.V. 
and M.P.; supervision, F.B., M.P.; funding acquisition, F.B., M.P. All authors have read and agreed to the published version of the manuscript.

Funding: This research was funded by Monton MMS Company, Dolinja Vas 27b, 52460 Momjan, Croatia.

Informed Consent Statement: Not applicable.

Data Availability Statement: Data available from the corresponding authors.

Acknowledgments: We are grateful to Monton MMS company and in particular to S. Šutej for giving ICTP Multidisciplinary Laboratory the opportunity to study the LiDAR data of the Oprtalj area, and to A. Krt, mayor of Oprtalj, for his support of the research.

Conflicts of Interest: The authors declare no conflict of interest.

\section{References}

1. Kvamme, K.L. Geophysical surveys as landscape archaeology. Am. Antiq. 2003, 68, 435-457.

2. Campana, S.; Piro, S. (Eds.) Seeing the Unseen-Geophysics and Landscape Archaeology; CRC Press: London, UK, 2009.

3. Opitz, R.S.; Cowley, D. Interpreting Archaeological Topography: Airborne Laser Scanning, 3D Data and Ground Observation; Oxbow Books: Oxford, UK, 2013.

4. Forte, M.; Campana, S. (Eds.) Digital Methods and Remote Sensing in Archaeology: Archaeology in the Age of Sensing; Springer: New York, NY, USA, 2017.

5. Campana, S. Mapping the Archaeological Continuum: Filling 'Empty' Mediterranean Landscapes; Springer: New York, NY, USA, 2018.

6. Leucci, G. Nondestructive Testing for Archaeology and Cultural Heritage: A Practical Guide and New Perspectives; Springer: Cham, Switzerland, 2019.

7. Piro, S.; Goodman, D. GPR Remote Sensing in Archaeology; Springer: Berlin, Germany, 2013.

8. Novo, A.; Leckebusch, J.; Goodman, D.; Morelli, G.; Piro, S.; Catanzariti, G. Advances in GPR imaging with multi-channel radar systems. J. Surv. Map. Eng. 2013, 1, 1-6.

9. Trinks, I.; Hinterleitner, A.; Neubauer, W.; Nau, E.; Löcker, K.; Wallner, M.; Gabler, M.; Filzwieser, R.; Wilding, J.; Schiel, H.; et al. Large-area high-resolution ground-penetrating radar measurements for archaeological prospection. Archaeol. Prospect. 2018, 25, 171-195.

10. Bernardini, F.; Vinci, G.; Horvat, J.; De Min, A.; Forte, E.; Furlani, S.; Lenaz, D.; Pipan, M.; Zhao, W.; Sgambati, A.; et al. Early Roman military fortifications and the origin of Trieste, Italy. Proc. Natl. Acad. Sci. USA 2015, 112, E1520-E1529. [PubMed]

11. Curry, S.; Stine, R.; Stine, L.; Nave, J.; Burt, R.; Turner, J. Terrestrial Lidar and GPR Investigations into the Third Line of Battle at Guilford Courthouse National Military Park, Guilford County, North Carolina. In Digital Methods and Remote Sensing in Archaeology: Archaeology in the Age of Sensing; Forte, M., Campana, S., Eds.; Springer: New York, NY, USA, 2017 ; pp. 53-70.

12. Gaffney, V.L.; Baldwin, E.; Bates, M.; Bates, C.R.; Gaffney, C.F.; Hamilton, D.; Kinnaird, T.; Neubauer, W.; Yorston, R.; Allaby, R.; et al. A massive, Late Neolithic pit structure associated with Durrington Walls Henge. Internet Archaeol. 2020, 55. [CrossRef]

13. Trinks, I.; Hinterleitner, A. Beyond Amplitudes: Multi-Trace Coherence Analysis for Ground-Penetrating Radar Data Imaging. Remote Sens. 2020, 12, 1583. [CrossRef]

14. Štular, B.; Lozić, E.; Eichert, S. Airborne LiDAR-Derived Digital Elevation Model for Archaeology. Remote Sens. 2021, 13, 1855. [CrossRef]

15. Cowley, D.C. Remote sensing for archaeological heritage management-Site discovery, interpretation and registration. In Proceedings of the 11th EAC Heritage Management Symposium, Reykjavik, Iceland, 25-27 March 2010; EAC Occasional Paper No. 5; Cowley, D.C., Ed.; Europae Archaeologiae Consilium: Brussels, Belgium, 2011; p. 312.

16. Cowley, D.; Banaszek, Ł.; Geddes, G.; Gannon, A.; Middleton, M.; Millican, K. Making LiGHT Work of Large Area Survey? Developing Approaches to Rapid Archaeological Mapping and the Creation of Systematic National-scaled Heritage Data. J. Comput. App. Archaeol. 2020, 3, 109-121. [CrossRef]

17. Bunting, C.; Branch, N.; Robinson, S.; Johnes, P. Ground penetrating radar as a tool to improve heritage management of wetlands. In Proceedings of the 15th International Conference on Ground Penetrating Radar 2014, Brussels, Belgium, 30 June-4 July 2014 ; pp. 54-59. [CrossRef]

18. Boschi, F. (Ed.) Looking to the Future, Caring for the Past. Preventive Archaeology in Theory and Practice; Bononia University Press: Bologna, Italy, 2016.

19. Neubauer, W. Die Entdeckung des Forums der Zivilstadt. In Carnuntum. Wiedergeborene Stadt der Kaiser; Humer, F., Ed.; Von Zabern: Darmstadt, Germany, 2014; pp. 88-89.

20. Filzwieser, R.; Ivanišević, V.; Verhoeven, G.J.; Gugl, C.; Löcker, K.; Bugarski, I.; Schiel, H.; Wallner, M.; Trinks, I.; Trausmuth, T.; et al. Integrating Geophysical and Photographic Data to Visualize the Quarried Structures of the Roman Town of Bassianae. Remote Sens. 2021, 13, 2384. [CrossRef]

21. Puente, I.; Solla, M.; Lagüela, S.; Sanjurjo-Pinto, J. Reconstructing the Roman Site "Aquis Querquennis" (Bande, Spain) from GPR, T-LiDAR and IRT Data Fusion. Remote Sens. 2018, 10, 379. [CrossRef] 
22. Verdonck, L.; Launaro, A.; Vermeulen, F.; Millett, M. Ground-penetrating radar survey at Falerii Novi: A new approach to the study of Roman cities. Antiquity 2020, 94, 705-723. [CrossRef]

23. Bernardini, F.; Vinci, G. Archaeological landscape in central northern Istria (Croatia) revealed by airborne LiDAR: From prehistoric sites to Roman centuriation. Archaeol. Anthropol. Sci. 2020, 12, 133. [CrossRef]

24. Felja, I.; Fontana, A.; Furlani, S.; Bajraktarević, Z.; Paradžik, A.; Topalović, E.; Rossato, S.; Ćosović, V.; Juračić, M. Environmental changes in the lower Mirna River valley (Istria, Croatia) during Upper Holocene. Geol. Croat. 2015, 68, 209-224. [CrossRef]

25. D'Incà, C. Il Porto Quieto e il fiume: Un mutare di funzioni e di paesaggi tra l'Istria costiera e l'interno. In Terre di Mare. L'archeologia dei Paesaggi Costieri e le Variazioni Climatiche; Snjezana, K., Auriemma, R., Eds.; Università degli Studi di Trieste-Pomorski Muzej: Trieste, Italy, 2008; pp. 155-161.

26. D'Ambrosi, C. Note illustrative alla Carta geologica delle Tre Venezie_Foglio "Pisino"; Società Cooperativa Tipografica: Padova, Italy, 1931.

27. Osović, V.; Moro, A. Geologia dell'Istria-Un'introduzione. In Giornate di Paleontologia 2006: Escursione nel Carso Triestino, in Slovenia e Croazia; EUT: Trieste, Italy, 2016; pp. 46-50.

28. Komšo, D. Pecina Laganiši, Mjestoživota i Smrt. Izložba-Exhibition; Arheološki muzej Istre: Pula, Croatia, 2008.

29. Mihovilić, K. Castellieri-Gradine of the Northern Adriatic. In The Oxford Handbook of the European Bronze Age; Harding, A., Fokkens, H., Eds.; Oxford University Press: Oxford, UK, 2013; pp. 864-876.

30. Buršić-Matijašić, K. Gradine Istre. Povijest prije Povijesti; ŽakanJuri: Pula, Croatia, 2007.

31. Grasmueck, M.; Weger, R.; Horstmeyer, H. Full-resolution 3D GPR imaging. Geophysics 2005, 70, K12-K19. [CrossRef]

32. Böniger, U.; Tronicke, J. Integrated data analysis at an archaeological site: A case study using 3D GPR, magnetic, and highresolution topographic data. Geophysics 2010, 75, B169-B176. [CrossRef]

33. Böniger, U.; Tronicke, J. Improving the interpretability of 3D GPR data using target-Specific attributes: Application to tomb detection. J. Archaeol. Sci. 2010, 37, 360-367. [CrossRef]

34. Novo, A.; Grasmueck, M.; Viggiano, D.A.; Lorenzo, H. 3D GPR in Archaeology: What can be gained from dense Data Acquisition and Processing? In Proceedings of the 12th International Conference on Ground Penetrating Radar, Birmingham, UK, 16-19 June 2008.

35. Stolt, R.H. Migration by Fourier Transforrm. Geophysics 1978, 43, 23-48. [CrossRef]

36. Borgna, E.; Càssola Guida, P.; Mihovilić, K.; Tasca, G.; Teržan, B. Bronzo Antico-Bronzo Recente. In Preistoria e Protostoria del 'Caput Adriae'; Borgna, E., Càssola Guida, P., Corazza, S., Eds.; Istituto di Preistoria e Protostoria: Firenze, Italy, 2018 ; pp. 75-96.

37. Codacci-Terlević, G. La scoperta della sepoltura a tumulo di Barbariga (Istria, Croazia). Novità e riscontri in relazione ai tumuli dell'età del bronzo rinvenuti nella penisola istriana e nell'Italia nord-orientale. In Ancestral Landscapes: Burial Mounds in the Copper and Bronze Ages (Central and Eastern Europe-Balkans-Adriatic-Aegean, 4th-2nd Millennium B.C.), Proceedings of the International Conference, Udine, Italy, 15-18 May 2008; Borgna, E., Müller-Celka, S., Eds.; Maison de l'Orient et de la Méditerranée: Lyon, France, 2012; pp. 153-162.

38. Mihovilić, K.; Hänsel, B.; Matošević, D.; Teržan, B. Burial Mounds of the Bronze Age at Mušego near Monkodonja. Results of the Excavations 2006-2007. In Ancestral Landscapes: Burial Mounds in the Copper and Bronze Ages (Central and Eastern EuropeBalkans-Adriatic-Aegean, 4th-2nd Millennium B.C.), Proceedings of the International Conference, Udine, Italy, 15-18 May 2008; Borgna, E., Müller-Celka, S., Eds.; Maison de l'Orient et de la Méditerranée: Lyon, France, 2012; pp. 367-373.

39. Hänsel, B.; Mihovilić, K.; Teržan, B. Monkodonja. Istraživanja Protourbanog na-selja Brončanog doba Istre. Knjiga 1. Iskopavanje i Nalazi Građevina/Monkodonja. Forschungen zu einer Protourbanen Siedlung der Bronzezeit Istriens. Teil 1. Die Grabung und der Baubefund; Monografije i katalozi/Monographien und Kataloge 25; Arheološki muzej Istre/Archäologisches Museum Istriens: Pula, Croatia, 2015.

40. Hänsel, B.; Mihovilić, K.; Teržan, B. Fortification Concepts of the Bronze Age Hillforts in Istria. In Bronze Age fortresses in Europe, Proceedings of the Second International LOEWE Conference, Alba Julia, Romania, 9-13 October 2017; Hanse, S., Rüdiger, K., Eds.; Verlag Dr. Rudolf Habelt GmbH: Bonn, Germany, 2019; pp. 99-115.

41. Cupitò, M.; Tasca, G.; Pulcini, M.L.; Carrara, N.; Lotto, D.; Gozzi, E.; Scaggio, C.; Canci, A.; Valzolgher, E. Il "sepolcreto gentilizio" del castelliere di Monte Orcino/Vrčin-Scavi Battaglia-Tamaro 1925-1928. Rilettura del contesto archeologico e risultati del riesame bioarcheologico dei resti umani. In Preistoria e Protostoria del 'Caput Adriae'; Borgna, E., Càssola Guida, P., Corazza, S., Eds.; Istituto di Preistoria e Protostoria: Firenze, Italy, 2018; pp. 509-526.

42. Vitasović, A. Gradina. Histria Archaeol. 2002, 31, 5-60.

43. Vitasović, A. La cultura dei castellieri sulle isole Brioni. In Carlo Marchesetti e i Castellieri, 1903-2003; Bandelli, G., Montagnari Kokelj, E., Eds.; Editreg: Trieste, Italy, 2005; pp. 301-324.

44. Recchia, G.; Cazzella, A. Coppa Nevigata in the wider context of Bronze Age fortified settlements of south-eastern Italy and the Adriatic area. In Bronze Age Fortresses in Europe, Proceedings of the Second International LOEWE Conference, Alba Julia, Romania, 9-13 October 2017; Hanse, S., Rüdiger, K., Eds.; Verlag Dr. Rudolf Habelt GmbH: Bonn, Germany, 2019; pp. 81-97.

45. Brown, K.A. A Passion for Excavation. Labour Requirements and Possible for the Ditches of the "Villaggi trincerati" of the Tavoliere, Apulia. Accord. Res. Pap. 1991, 2, 7-30. 